\title{
Antimicrobial Effect of Dietary Supplementation of Turmeric Powder in Intestine of Broilers
}

\author{
Parveen Kumar Ahlawat ${ }^{*}$, Rajesh Dalal, Sonu, B.S. Tewatia, \\ V.S. Panwar and Nancy Sheoran
}

Department of Animal Nutrition, College of Veterinary Sciences, Lala Lajpat Rai University of Veterinary and Animal Sciences, Hisar, Haryana, India

*Corresponding author

\begin{tabular}{l} 
Ke y w o r d s \\
$\begin{array}{l}\text { Antimicrobial, Broilers, } \\
\text { E. coli, Intestinal } \\
\text { bacteriology, } \\
\text { Lactobacilli, Turmeric }\end{array}$ \\
\hline Article Info \\
$\begin{array}{l}\text { Accepted: } \\
20 \text { March } 2018 \\
\text { Available Online: } \\
\text { 10 April } 2018\end{array}$ \\
\hline
\end{tabular}

\section{A B S T R A C T}

To study antimicrobial effects of supplementation of turmeric on intestine of broilers, three hundred, one day old commercial broiler chicks were taken for the experiment. The chicks were distributed randomly to six dietary treatments having five replicates each and ten birds per replicate. Maize-soybean meal based diet served as the basal diet. The basal diet without antibiotic was given to treatment $T_{1}$. Treatment group $T_{2}$ was offered basal diet with antibiotic. In treatment groups $\mathrm{T}_{3}, \mathrm{~T}_{4}, \mathrm{~T}_{5}$ and $\mathrm{T}_{6}$, basal diet was supplemented with turmeric @ 0.25, 0.50, 0.75 and 1.0\%, respectively. Total E. coli count (log cfu/g) was recorded lowest in $\mathrm{T}_{4}$ (4.55) as compared to control group $\mathrm{T}_{1}$ (7.58). Other turmeric supplemented groups also showed significant reduction in the Coliform count as compared to control group. The total Lactobacilli count (log $\mathrm{cfu} / \mathrm{g}$ ) showed an increment among different turmeric powder supplemented treatments. Lactobacilli count was observed highest in turmeric supplemented group @ 0.75\% (7.55) as compared to the control group (4.64). So from the above obtained results on intestinal bacteriology, it can be concluded that turmeric results in reduction of pathogenic bacteria and increment of beneficial bacteria.

\section{Introduction}

In the present era, broiler industry as a part of poultry industry has been developing at a satisfactory level. The main goal of broiler industry is to achieve optimum weight gain with efficient feed utilization keeping the survivability of the broilers as maximum as possible which could be achieved by use of specific feed additives. Feed additives increases feed conversion ratio, growth rate and survivability (Feltwell and Fox, 1979).
Poultry are vulnerable to pathogenic microorganisms in the small intestine. This leads to depressed growth and increased incidences of diseases. Herbal products like turmeric control the pathogenic microorganism by creating favorable conditions in intestine. Herbs provide beneficial effect on health due to the antimicrobial activity (Lee et al., 2004). Turmeric possess anti-inflammatory (Ammon et al., 1993), antioxidative (Osawa et al., 1995), anticoccidials (Allen and Fetterer, 
2002; Abbas et al., 2010) and immunomodulatory (Kumari et al., 2007; Yarru et al., 2009) properties.This study was planned to study the antimicrobial effects of turmeric powder in intestine of broilers.

\section{Materials and Methods}

\section{Selection of chicks}

Three hundred, one day old broiler chicks, were purchased from a local commercial hatchery. The chicks were individually weighed, wing banded and randomly distributed into 30 subgroups means six dietary treatments with five replicates per treatment and each replicate has ten birds. The first group was kept as a control $\left(\mathrm{T}_{1}\right)$ and given the basal diet without antibiotic while second $\left(\mathrm{T}_{2}\right)$ basal diet with antibiotic, third $\left(T_{3}\right)$, fourth $\left(T_{4}\right)$, fifth $\left(T_{5}\right)$ and sixth $\left(T_{6}\right)$ groups were supplemented with turmeric powder@ 0.25, 0.5, 0.75 and 1\%, respectively in the diet. Birds were vaccinated against F1 strain of Ranikhet disease on $3^{\text {rd }}$ day and IBD on $14^{\text {th }}$ day.

\section{Housing and brooding}

The experimental chicks were reared under deep litter system. The floor of the pens was thoroughly cleaned, disinfected before scattering of the bedding material. Well chopped dry wheat straw was used as bedding material. The straw was evenly spread up to 5 $\mathrm{cm}$ thickness. The litter was regularly racked to avoid any lump formation. Wooden brooders fitted with bulb in the centre were used in each pen for brooding.

\section{Feeding and watering}

During the initial period of growth, extra care was taken to assure efficient feeding and watering of the chicks so that they could be well introduced and acclimatized. The feeding programme consisted of a starter diet until 28 days and a finisher diet from 28 to 42 days of age. Weighed amount of feed was offered on paper sheets for first 3 days and thereafter, in the automatic feeders up to 28 days of age. Afterwards, the feeds were offered through hanging feeders maintained at appropriate heights. The chicks were provided ad libitum clean drinking water through the plastic waterers during first two weeks of the experiment. Thereafter, bigger plastic waterers were used till the end of the experiment.

All feed ingredients, additives and supplements used in the experiment were procured in one lot before the start of the experiment. The ingredients, additives and supplements used in the diet formulations were maize, soybean meal, vegetable oil, fish meal, mineral mixture, vitamins, coccidiostat, lysine, DL- methionine and turmeric powder. The sources, composition and mixing rate of additives/supplements used in ration formulations are presented in Table 2.

\section{Evaluation of feed ingredients}

Feed ingredients used for ration formulations were evaluated for proximate nutrients (AOAC, 2013). The evaluated and measured values of feed ingredients used in preparing the experimental diets are presented Table 1 .

\section{Composition of diets}

Basal ration was formulated as per BIS (2007) to fulfill the metabolizable energy (ME) and crude protein requirements of birds (Table 3 ). Level of crude protein in starter (0-4weeks) and finisher (4-6weeks) ration was 22 and 20 $\%$, respectively. The respective ME content was 3000 and $3200 \mathrm{KCal} / \mathrm{kg}$ are presented in Table 1.

The experimental dietary treatments were as under: 
$\mathrm{T}_{1}$ : Basal diet without antibiotic

$\mathrm{T}_{2}$ : Basal diet with antibiotic

$\mathrm{T}_{3}$ : Basal diet $+0.25 \%$ turmeric powder

$\mathrm{T}_{4}$ : Basal diet $+0.50 \%$ turmeric powder

$\mathrm{T}_{5}$ : Basal diet $+0.75 \%$ turmeric powder

$\mathrm{T}_{6}$ : Basal diet $+1.00 \%$ turmeric powder

\section{Intestinal microbial count}

For intestinal microbial count, the ileal contents were collected aseptically. Samples were weighed $(1 \mathrm{~g})$, transferred to sterile tubes and homogenized with sterile $0.9 \%$ normal saline solution (1:1). Then the solutions were mixed on vortex. Serial dilutions of samples were made up to six dilutions. $0.1 \mathrm{~mL}$ of each dilution was poured and spread uniformly on MacConkey lactose agar for $E$. coli and on nutrient agar for lactobacilli. Plates were incubated at $37^{\circ} \mathrm{C}$ for $24 \mathrm{~h}$. The average number of colonies was multiplied by reciprocal of the dilution factor and expressed as log cfu/g of contents.

\section{Results and Discussion}

Average feed intake did not differ significantly during the whole experimental period but it was numerically higher in treatment group $\mathrm{T}_{2}(2115 \mathrm{~g})$ as compared to control group and other turmeric supplemented groups as presented in Table 4 . During the whole experimental period, the average body weight gain in treatment group $\mathrm{T}_{4}(2239.7 \mathrm{~g})$ was significantly higher as compared to control group (2001.2 g) and other dietary treatment groups (Table 4). Treatment group $\mathrm{T}_{1}$ had the lowest body weight gain. Feed conversion ratio in groups with turmeric supplementation @ $0.5 \%$ (1.77) was significantly better compared to the control group and non-significantly better than other treatments as depicted in Table 4.

Total E. coli. count (log cfu/g) ranged from $4.55\left(\mathrm{~T}_{4}\right)$ to $7.58\left(\mathrm{~T}_{1}\right)$ among different dietary treatments as presented in Table 5. The significant reduction in the Coliform count as shown in Figure 1 was observed in turmeric supplemented group @ $0.5 \%$ (4.55) in comparison to the control group (7.58). Other turmeric supplemented treatment groups also showed significant reduction in the Coliform count as compared to control group.

The total Lactobacilli count $(\log \mathrm{cfu} / \mathrm{g})$ ranged from $4.64\left(\mathrm{~T}_{1}\right)$ to $7.55\left(\mathrm{~T}_{5}\right)$ among different dietary treatments as presented in Table 5. Significant increment in the Lactobacilli count as shown in Figure 2 was observed in turmeric supplemented group @ 0.75\% (7.55) in comparison to the control group (4.64). Other turmeric supplemented treatment groups also showed significant increase in the Lactobacilli count as compared to control group.

There was no effect of turmeric supplementation on feed intake of broilers. The findings of present study are in accordance with findings of Akbarian et al., (2012) who recorded that feed intake of broilers during different weeks were not influenced by turmeric powder supplementation. Consistent with results of present study, Rajput et al., (2013) recorded that the feed intake of birds fed diet containing curcumin @ $100 \mathrm{mg} / \mathrm{kg}(4.38 \mathrm{~kg}), 150 \mathrm{mg} / \mathrm{kg}$ $(4.45 \mathrm{~kg})$ and $200 \mathrm{mg} / \mathrm{kg}(4.42 \mathrm{~kg})$ did not differ significantly as compared to the control group $(4.41 \mathrm{~kg})$. In agreement with findings, Naderi et al., (2014) also recorded no significant effect of turmeric supplementation on feed intake in broilers. Feed intake of birds fed diet containing turmeric @ $2.5 \mathrm{~g} / \mathrm{kg}$ of feed $(4242 \mathrm{~g})$ and $7.5 \mathrm{~g} / \mathrm{kg}$ of feed $(4310 \mathrm{~g})$ was at par as compared to the control group (4270 g).

With respect to the whole experimental period the average body weight gain in $T_{4}$ was significantly higher as compared to control and other groups. 
Table.1 Chemical composition of feed ingredients used in ration formulation

\begin{tabular}{|l|c|c|c|c|c|c|c|}
\hline Ingredient & $\begin{array}{c}\text { CP } \\
(\%)\end{array}$ & $\begin{array}{c}\text { CF } \\
(\%)\end{array}$ & $\begin{array}{c}\text { EE } \\
(\%)\end{array}$ & $\begin{array}{c}\text { TA } \\
(\%)\end{array}$ & $\begin{array}{c}\text { Lysine* } \\
(\%)\end{array}$ & $\begin{array}{c}\text { Methionine* } \\
(\%)\end{array}$ & $\begin{array}{c}\text { MIE* } \\
(\mathrm{kcal} / \mathrm{kg})\end{array}$ \\
\hline Maize & 9.11 & 2.44 & 3.44 & 2.25 & 0.18 & 0.15 & 3300 \\
\hline Soybean meal & 45.15 & 3.93 & 3.16 & 8.47 & 2.57 & 0.76 & 2230 \\
\hline Fish meal & 47.40 & 1.79 & 5.16 & 26.62 & 1.42 & 1.42 & 2210 \\
\hline
\end{tabular}

*Calculated values (Singh and Panda, 1992)

Table.2 Ingredient composition of experimental diets during different phases of growth

\begin{tabular}{|l|c|c|}
\hline Ingredient $(\mathrm{kg} / \mathbf{1 0 0}$ of feed) & $\mathbf{0 - 4} \mathrm{wk}$ & $\mathbf{4 - 6} \mathbf{~ k}$ \\
\hline Maize & 58 & 60 \\
\hline Soybean meal & 30 & 25 \\
\hline Fish meal & 7 & 7 \\
\hline Vegetable oil & 3 & 6 \\
\hline Mineral mixture & 2 & 2 \\
\hline Feed additives (g/100 kg feed) & 10 & \\
\hline Spectromix* & 20 & 10 \\
\hline Spectromix BE* & 50 & 20 \\
\hline Veldot* & 50 & 50 \\
\hline Choline chloride* & 50 & 50 \\
\hline Lysine* & 150 & 50 \\
\hline DL-methionine* & & 150 \\
\hline
\end{tabular}

*Composition, sources and rate of mixing of feed additives/supplements

1. $\quad$ Spectromix: Powder (Ranbaxy Animal Health, New Delhi). Each g. contained VitaminA-82,500 IU, Vit D3$12000 \mathrm{IU}$, Vit B2-50 mg and Vit.K-10 mg. Mixing rate: $10 \mathrm{~g} / 100 \mathrm{~kg}$ of feed.

2. Spectromix BE: Powder (Ranbaxy Animal Health, New Delhi). Each g contained Vit.B1- 8 mg, Vit.B6- 16 $\mathrm{mg}$, Vit.B12- $80 \mathrm{mg}$, niacin-120mg, calcium pentothenate- $80 \mathrm{mg}$, Vit. E-160 mg, Lysine hydrochloride-10 $\mathrm{mg}$, DL-methionine-10 $\mathrm{mg}$ and calcium $260 \mathrm{mg}$. Mixing rate: $20 \mathrm{~g} / 100 \mathrm{~kg}$ of feed.

3. Veldot: Venkeys- Dinitro-O-Toluamide (Coccidiostat). Mixing rate: $50 \mathrm{~g} / 100 \mathrm{~kg}$ of feed.

4. Choline chloride: Contain 60 percent choline. Mixing rate: $50 \mathrm{~g} / 100 \mathrm{~kg}$ of feed.

5. Lysine: Contained $98 \%$ lysine. Mixing rate: $50 \mathrm{~g} / 100 \mathrm{~kg}$ of feed.

6. DL-methionine: Contained 98\% methionine. Mixing rate: $150 \mathrm{~g} / 100 \mathrm{~kg}$ of feed.

Table.3 Chemical composition (\% DM basis) of experimental diets in different growth phases of broiler chicks

\begin{tabular}{|c|c|c|}
\hline Attribute & $0-28 d$ & $29-42 \mathrm{~d}$ \\
\hline DM & 88.79 & 88.59 \\
\hline CP & 22.92 & 20.32 \\
\hline EE & 3.32 & 3.62 \\
\hline CF & 5.12 & 5.19 \\
\hline ASH & 9.15 & 9.25 \\
\hline NFE & 59.49 & 61.62 \\
\hline
\end{tabular}


Table.4 Average feed intake, body weight gain and feed conversion ratio of broilers under different dietary treatments

\begin{tabular}{|c|c|c|c|}
\hline Treatment & $\begin{array}{c}\text { A verage feed intake } \\
\text { A verage body weight gain }\end{array}$ & $\begin{array}{c}\text { Feed conversion } \\
\text { ratio }\end{array}$ \\
\hline $\mathrm{T}_{1}$ & $3891.0 \pm 67.9$ & $2001.2^{\mathrm{a}} \pm 12.8$ & $1.94^{\mathrm{c}} \pm 0.04$ \\
\hline $\mathrm{T}_{2}$ & $3966.1 \pm 26.7$ & $2103.2^{\mathrm{bc}} \pm 35.3$ & $1.88^{\mathrm{bc}} \pm 0.04$ \\
\hline $\mathrm{T}_{3}$ & $3916.3 \pm 30.2$ & $2067.7^{\mathrm{b}} \pm 20.5$ & $1.89^{\mathrm{bc}} \pm 0.02$ \\
\hline $\mathrm{T}_{4}$ & $3972.9 \pm 64.5$ & $2239.7^{\mathrm{e}} \pm 12.6$ & $1.77^{\mathrm{a}} \pm 0.04$ \\
\hline $\mathrm{T}_{5}$ & $3991.3 \pm 27.7$ & $2171.6^{\mathrm{d}} \pm 17.9$ & $1.83^{\mathrm{abc}} \pm 0.02$ \\
\hline $\mathrm{T}_{6}$ & $3886.1 \pm 38.0$ & $2138.1^{\mathrm{cd}} \pm 13.0$ & $1.81^{\mathrm{ab}} \pm 0.01$ \\
\hline
\end{tabular}

*Values bearing different superscripts in a column differ significantly $(\mathrm{P}<0.05)$

Table.5 Total Coliform (log cfu/g) and total Lactobacilli $(\log \mathrm{cfu} / \mathrm{g}$ ) count of the ileal content of the experimental birds under different dietary treatments

\begin{tabular}{|c|c|c|}
\hline Treatment & Coliform $(\log \mathrm{cfu} / \mathrm{g})$ & Lactobacilli $(\log$ cfu/g) \\
\hline $\mathrm{T}_{1}$ & $7.58^{\mathrm{e}} \pm 0.02$ & $4.64^{\mathrm{a}} \pm 0.02$ \\
\hline $\mathrm{T}_{2}$ & $5.57^{\mathrm{c}} \pm 0.03$ & $5.55^{\mathrm{b}} \pm 0.03$ \\
\hline $\mathrm{T}_{3}$ & $6.45^{\mathrm{d}} \pm 0.04$ & $5.63^{\mathrm{b}} \pm 0.03$ \\
\hline $\mathrm{T}_{4}$ & $4.55^{\mathrm{a}} \pm 0.02$ & $6.63^{\mathrm{d}} \pm 0.03$ \\
\hline $\mathrm{T}_{5}$ & $5.42^{\mathrm{b}} \pm 0.04$ & $7.55^{\mathrm{e}} \pm 0.05$ \\
\hline $\mathrm{T}_{6}$ & $5.54^{\mathrm{c}} \pm 0.01$ & $6.47^{\mathrm{c}} \pm 0.05$ \\
\hline
\end{tabular}

${ }^{\text {abc }}$ Means bearing different superscripts in a column differ significantly $(\mathrm{P}<0.05)$

Fig.1 E. coli count (log cfu/g) of ileal content under different dietary treatments

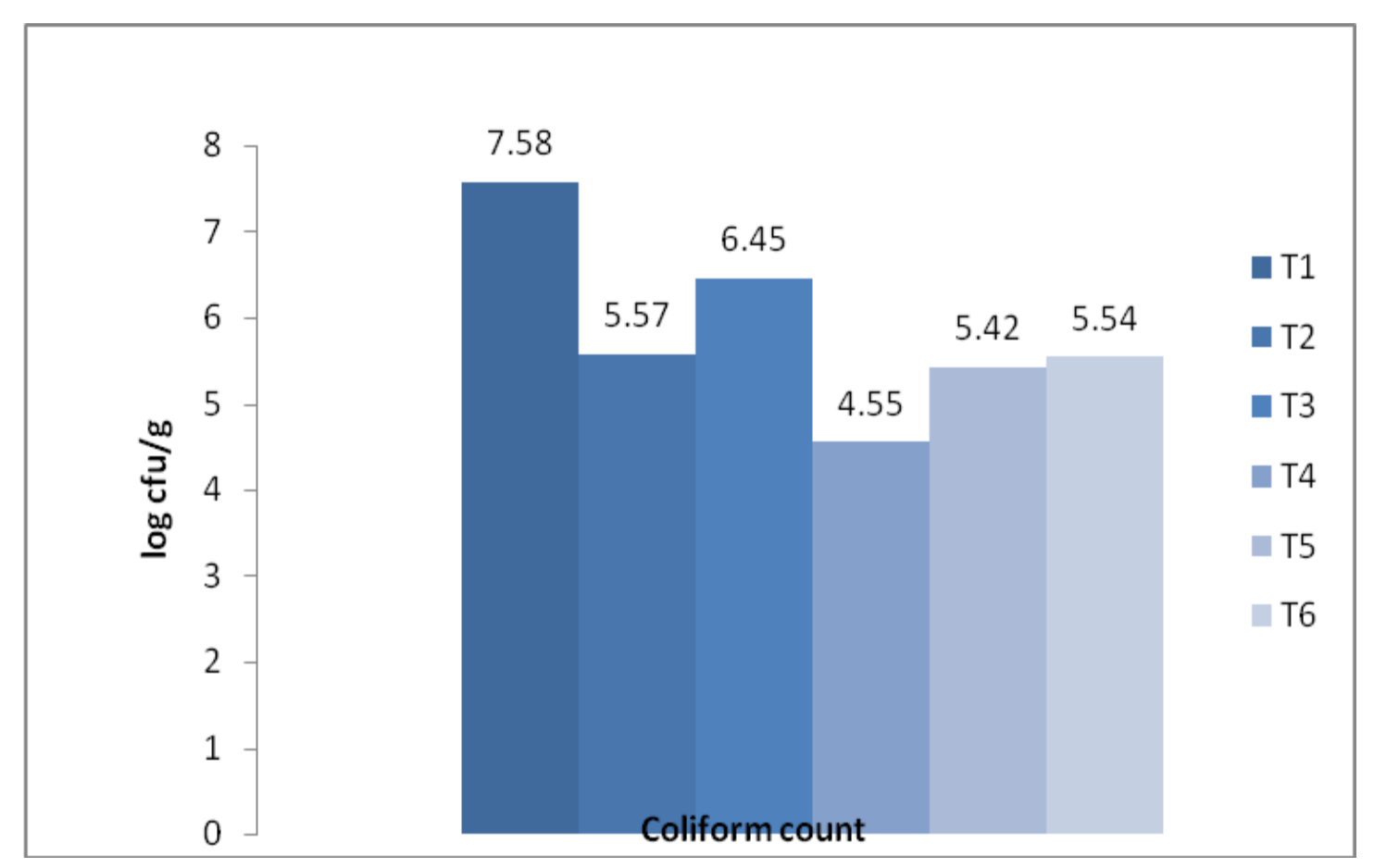


Fig.2 Total lactobacilli count (log cfu/g) of ileal content under different dietary treatments

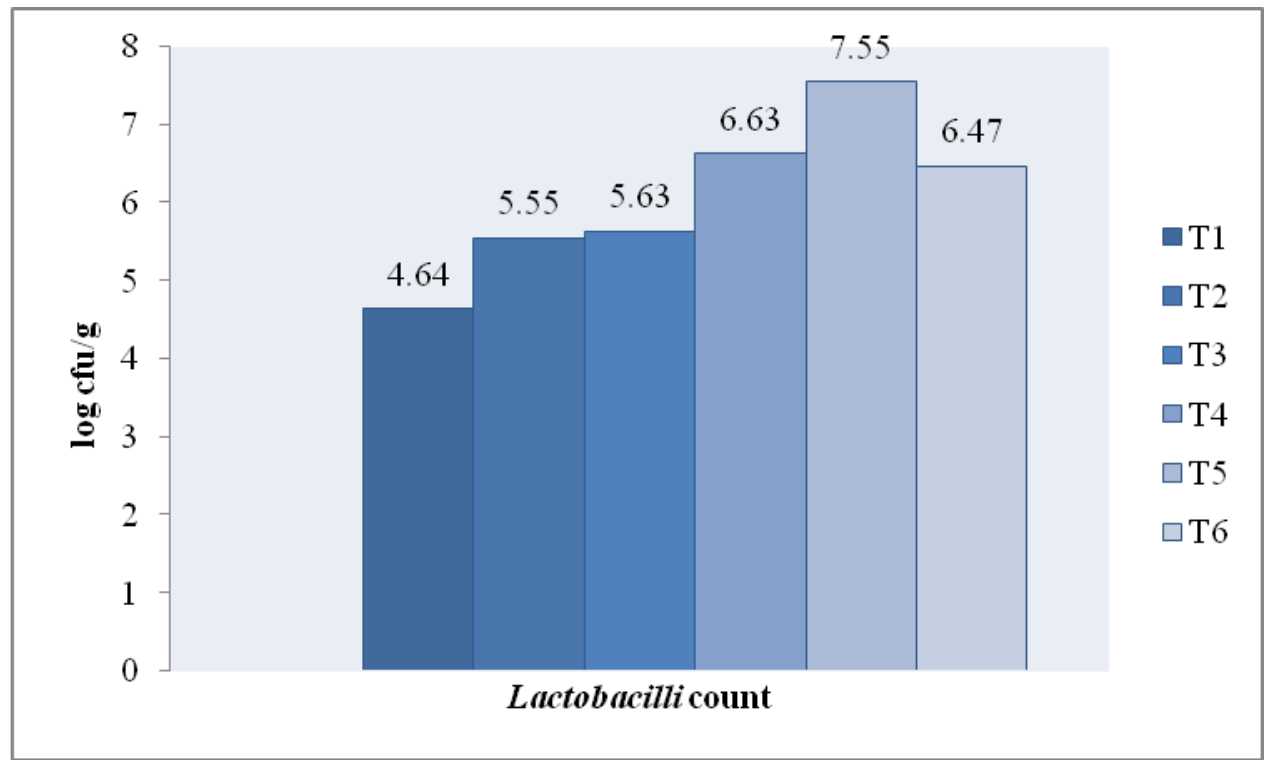

These findings concur with the results of $\mathrm{Al}$ Sultan (2003) who investigated the effect of Curcuma longa (turmeric) feed additive on overall performance of broiler chickens. The effect of different dietary levels of turmeric inclusion $(0.25,0.5$ and $1.0 \%)$ on body weight gain was recorded as compared to the control group. The higher body weight gain (1344.5 g) was observed in birds fed diet contained turmeric at level of $0.5 \%$ followed by birds which received $0.25 \%$ (1329.8 g), 1\% (1306 g) and control (1268.2 g). Durrani et al., (2006) revealed that highest average body weight gain (734 g) was recorded in birds fed diet containing turmeric at the level of $5 \mathrm{~g} / \mathrm{kg}$ of feed but it was not significantly different as compared to the control group (646 g).

At 42 days of age, FCR of the treatment group with turmeric supplementation@ 0.5 $\%$ (1.77) was significantly better as compared to the control group (1.94). These results are in accordance with Al-Sultan (2003) who observed that the feed conversion ratio of birds receiving turmeric @ $0.5 \%$ in their diets was the best (2.08) as compared to controls (2.47) and other treated groups (2.27 and
2.31). The results concur with the findings of Naderi et al., (2014) who recorded significantly better feed conversion ratio in birds fed diet containing turmeric @ $2.5 \mathrm{~g} / \mathrm{kg}$ (1.85) as compared to the control group (1.93). However, feed conversion ratio of birds receiving turmeric supplementation @ $7.5 \mathrm{~g} / \mathrm{kg}$ of feed (1.96) was at par as compared to the control group (1.93).

The coliform count of the birds receiving diet supplemented with turmeric powder at the level of $0.5 \%$ was significantly lower as compared with the control and other turmeric powder supplemented groups. The control group receiving basal diet showed significantly higher coliform count in comparison to all other groups. Also, the coliform count of birds receiving turmeric at the rate of $1 \%$ in their diet did not differ significantly in comparison to birds receiving diet containing antibiotic. Consistent with our results Samarasinghe et al., (2003) revealed that colony forming units (cfu) of coliform bacteria, yeast and mould significantly reduced $(\mathrm{P}>0.05)$ when the diet was supplemented with turmeric, 
mannonoligosaccharide or virginiamycin. However, in contrast to our results Hanan E. Al-Mashhadani (2015) recorded that dietary supplementation of turmeric powder did not have significant $(\mathrm{P}>0.05)$ effect on $E$. coli count. However, E. coli count was numerically lower in all supplemented groups as compared to the control group.

The results of the present study revealed that the total Lactobacilli count of the birds receiving diet containing turmeric powder @ $0.75 \%$ was significantly higher as compared to control and other turmeric supplemented groups. The control group receiving basal diet showed significantly lower Lactobacilli count in comparison to all other groups. Consistent with results of present study, Hanan E. AlMashhadani (2015) recorded that dietary supplementation of turmeric powder caused a significant $(\mathrm{P}<0.05)$ increase in Lactobacillus count compared with the control group. So from the results obtained from the experiment it was depicted that dietary supplementation of turmeric powder decreases the pathogenic bacterial count like E. coli simultaneously increasing beneficial bacteria like Lactobacillus by creating a favorable intestinal environment for their growth.

Supplementation of turmeric powder in the diet of broilers resulted in increased average body weight gain and better feed conversion ratio. Dietary supplementation of turmeric powder in broilers resulted in balanced intestinal microbial environment due to decreased colonization of $E$. coli and increased lactobacilli count Thus, there was efficient utilization of feed which resulted in enhanced survivability the broilers.

Considering the results obtained in the present experiment, It could be concluded that supplementation of turmeric @0.5\% has the potential to improve intestinal microbial ecosystems by increasing lactobacillus count.
So, turmeric could be used as an alternative to antibiotics as a growth promoter.

\section{References}

Abbas, R.Z., Iqbal, Z., Khan, M.N., Zafar, M.A. and Zia, M.A. 2010. Anticoccidial activity of Curcuma longa L. in broilers. Brazil Arch. Biol. Technol. 53: 63-67.

Akbarian, A., Golian, A., Kermanshahi, H., Gilani, A. and Moradi, S. 2012. Influence of turmeric rhizome and black pepper on blood constituents and performance of broiler chickens. Afr. J.Biotech. 11(34): 8606-8611.

Allen, P.C. and Fetterer, R.H. 2002. Recent advances in biology and immunobiology of Eimeria species and in diagnosis and control of infection with these coccidian parasites of poultry. Clin. Microbiol. Rev. 15:58-65.

Al-Mashhadani, H.E. 2015. Effect of different levels of turmeric (Curcuma longa) supplementation on broiler performance, carcass characteristic and bacterial count. Egypt Poult. Sci. 35 (1): $25-39$.

Al-Sultan, S.I. 2003. The effect of Curcuma longa (turmeric) on overall performance of broiler chickens. Int. J. Poult. Sci. 3: 333-340.

Ammon, H.P., Safayhi, H., Mack, T. and Sabieraj, J. 1993. Mechanism of antiinflammatory actions of curcumin and boswellic acids. J. Ethnopharmacol. 38:113-119.

AOAC. 2013. Official Methods of Analysis. $16^{\text {th }}$ edn. Association of Official Analytical Chemists. Arlington, Virginia, USA.

BIS. 2007. Nutrient Requirements of Poultry IS: 1374. Bureau of Indian Standards, New Delhi, India.

Durrani, F.R., Ismail, M., Sultan, A., Suhail, S.M., Chand, N. and Durrani, Z. 2006. Effect of different levels of feed added 
turmeric (Curcuma longa) on the performance of broiler chicks. J. Agril. Biol. Sci. 1: 9-11.

Felt-Well, R. and Fox, S. 1979. Practical Poultry Feeding. ELBS and Faber co. London.

Kumari, P., Gupta, M.K., Ranjan, R.K., Singh, K.K. and R, Yadav. 2007. Curcuma longa as feed additive in broiler birds and its pathophysiological effects. Indian J. Exp. Biol. 45: 272-277.

Lee, K.W., H. Everts, and, A.C. Beynen. 2004. Essential oils in broiler nutrition. Int.J. Poult. Sci. 3; 738-752.

Naderi, M., Akbari, MR., Asadi-Khoshoei, E., Khaksar, K. and Khajali, F. 2014. Effects of Dietary Inclusion of Turmeric (Curcuma longa) and Cinnamon (Cinnamomum verum) Powders on Performance, Organs Relative Weight and Some Immune System Parameters in Broiler Chickens. Poult. Sci. J. 2014. 2 (2): 153-163.

Osawa, T., Sugiyama, Y., Inayoshi, M. and Kawakisi, S. 1995. Anti-oxidative activity of tetrahydrocurcuminoids. Biotech. Biochem. 59: 1609-1610.
Rajput, N., Muhammad, N., Yan, R., Zhong, X. and Wang, T. 2013. Effect of Dietary Supplementation of Curcumin on Growth Performance, Intestinal Morphology and Nutrients Utilization of Broiler Chicks. J. Poult. Sci. 50: 4452.

Samarasinghe, K., Wenk, C., Silva, K. and J. M. D. M. Gunasekera, J. 2003. Turmeric (Curcuma longa) Root Powder and Mannanoligosaccharides as Alternatives to Antibiotics in Broiler Chicken Diets. Asian-Aust. J. Anim. Sci. 16(10): 1495-1500.

Singh, K.S. and Panda, S.1992. Feed additives. In: Poultry Nutrition. $2^{\text {nd }}$ edn. Kalyani Publ. Delhi.

Yarru, L.P., Settivari, R.S., Gowda, N.K.S., Antoniou, E., Ledoux, D.R. and Rottinghaus, G.E. 2009. Effects of turmeric (Curcuma longa) on the expression of hepatic genes associated with biotransformation, antioxidant, and immune systems in broiler chicks fed aflatoxin. Poult Sci. 88:2620-262.

\section{How to cite this article:}

Parveen Kumar Ahlawat, Rajesh Dalal, Sonu, B.S. Tewatia, V.S. Panwar and Nancy Sheoran. 2018. Antimicrobial Effect of Dietary Supplementation of Turmeric Powder in Intestine of Broilers. Int.J.Curr.Microbiol.App.Sci. 7(04): 2244-2251. doi: https://doi.org/10.20546/ijcmas.2018.704.256 